\title{
The Bambuí Health and Aging Study (BHAS): factors associated with hospitalization of the elderly
}

\author{
Projeto Bambuí: fatores associados a internações \\ hospitalares entre idosos na comunidade
}

Henrique L. Guerra 1,2,3

Josélia O. A. Firmo 1,2,3

Elizabeth Uchoa 2,3,4

Maria Fernanda F. Lima-Costa 2,3,5

1 Escola Nacional de Saúde Pública, Fundação Oswaldo Cruz. Rua Leopoldo Bulhões 1480, Rio de Janeiro, RJ

21041-210, Brasil.

2 Núcleo de Estudos sobre Epidemiologia e Antropologia do Envel hecimento, Centro de Pesquisas René Rachou, Fundação Oswal do Cruz. Av. Augusto de Lima 1715, Belo Horizonte, MG 30190-002, Brasil.

3 Laboratório de Epidemiologia e Antropologia Médica, Centro de Pesquisas René Rachou, Fundação Oswaldo Cruz. Av. Augusto de Lima 1715, Belo Horizonte, MG

30190-002, Brasil.

4 Departamento de Psiquiatria e Neurologia, Faculdade de Medicina, Universidade Federal de Minas Gerais. Av. Alfredo Balena 190, Belo Horizonte, MG 30130-100, Brasil. 5 Departamento de Medicina Preventiva e Social,

Faculdade de Medicina, Universidade Federal de Minas Gerais. Av. Alfredo Balena 190, Belo Horizonte, MG 30130-100, Brasil.
Abstract This study aimed to identify factors associated with hospital admissions of the elderly. All residents of Bambuí, Minas Gerais State $\geq 60$ years $(n=1,742)$ were selected. Some 1,606 of these (92.2\%) partici pated in the study. The dependent variable was the number of hospital admissions (none, one, and two or more) during the previous 12 months. Independent variables were grouped as enabling, predisposing, and need-rel ated factors. The strongest associations with multiple hospital admissions were: Iiving alone; financial constraints to purchase of medication; and various indicators of need (worse self-perceived health, more visits to physi cian, greater use of prescription medications, and history of coronary heart disease). Such variables could help identify older adults at greatest risk and thus prevent hospitalization.

Key words Aging; Health Services Accessibility; Hospitalization

Resumo O estudo procura identificar fatores associados com internação hospitalar entre idosos. Foram sel eci onados todos os adultos resi dentes em Bambuí, Minas Gerais, com 60 ou mais anos ( $n=1.742)$. Deste total, $1.606(92,2 \%)$ parti ci param no estudo. A variável dependente era o número de internações hospitalares $(0,1$ ou $\geq 2)$ nos últimos 12 meses. As variávei s independentes foram classi ficadas como faci litadoras, predisponentes e rel acionadas a necessidades. As variáveis independentes que demonstraram associ ações mais fortes com o número de internações hospitalares foram: o fato de viver sozinho(a); restrições financei ras à aqui si ção da medicação prescrita e di versos indicadores de necessi dade (percepção negativa da própria saúde, número maior de consultas médicas, mai or uso de medicação com receita médica e história de doença coronariana). Estas variávei s poderiam ajudar a identificar os idosos com risco el evado de hospitalização e contri buir para medi das preventivas.

Palavras-chave Envel heci mento; Acesso aos Serviços de Saúde; Hospitalização 


\section{Introduction}

Ageing of the population was a phenomenon initially observed in developed countries, but in recent years the number of older adults in developing nations has increased more rapidly. Projections recently published by the World Health Organization (WHO) estimate that between 1990 and 2,025 the elderly population will increase by approximately seven to eight times in countries such as Colombia, Malaysia, Kenya, Thailand and Ghana. The same projections indicate that five of the 10 countries with the highest population of older adults in 2025 will be developing countries, including Brazil, where an estimated number of 27 million people will be over 60 years old (WHO, 1998). The proportion of people aged 60 or older years in Brazil increased from $6.1 \%$ in $1980(7,204,517$ inhabitants) to $7.9 \%$ in 1996 (12,398,678 inhabitants), corresponding in absolute numbers to an increase of 5.2 million individuals (IBGE, 1981, 1997).

The increase of the elderly population implies a greater number of health problems, with the highest demand for health care services concentrated within this group (Kalache et al., 1987; Lima-Costa et al., 2000a; Ramos et al., 1987; Taket, 1992; Veras et al., 1987). In Brazil, the costs of hospital public admissions for individuals aged $\geq 60$ years, who comprised $7.9 \%$ of the population of the country in 1996, will reach $27.2 \%$ of the total this year (Lima-Costa et al., 2000a). It is known also that the high cost of health services utilized by the older adult population, principally hospital admissions, is concentrated in a small subgroup of this popuIation (Freeborn et al., 1990; McCall \& Wai, 1983; Roos \& Shapiro, 1981; Roos et al., 1989; Zook \& Moore, 1980). Members of this minority could have a better health situation with less frequent hospital admissions, if they could be identified in advance and treated preventively (Boult et al., 1993). Thus, knowledge of the factors associated with hospital admissions among the elderly is important to prevent these, or at least to organize the provision of services at the hospital, ambulatory, community and household level (Boult et al., 1993, 1994; Evans et al., 1988; Pacala et al., 1995), in order to produce a positive impact on the quality of life for older adults and rationalize treatment costs.

Since the behavioral model was proposed to investigate the determinants of health service utilization in the early 1970s (Aday \& Andersen, 1974; Andersen \& Newman, 1973), various studies have been carried out in developed countries to identify the factors associated with use of the health services by older people (Branch et al., 1981; Coleman et al., 1998; Evans et al., 1988; Satish, 1996; Wolinsky et al., 1992). More recently, population-based studies have been carried out in developed countries to identify predictive characteristics for hospital admissions in this population (Boult et al., 1993; Hurd \& McGarry, 1997; Pacala et al., 1997). In general, these have shown that the most important variables are: poor self-perceived health status, more advanced age, greater number of visits to a doctor in the previous year, greater number of medications utilized, disability to perform some activities of daily living (ADL) and presence of certain diseases, such as coronary disease and diabetes, among others. It is not known, however, if these variables are capable of predicting hospital admissions among older adult residents of developing countries.

The factors associated with the utilization of health services (ambulatory, hospital and others) in developing countries were investigated based on cross sectional studies developed in Mexico (Borges-Yáñez \& Gómes-Dantés, 1998) and Brazil (Pinheiro \& Travassos, 1999). The former study, based on information from a national health survey carried out in 1994, verified that more advanced age, inability to work during the previous week, access to social security, and report of previous diagnosis of any disease were associated with utilization of health services. In the latter study, carried out in the city of Rio de Janeiro, it was verified that the factors associated with the utilization of health services by the elderly were female sex, access to private health plan, residence in richest areas of the city and history of prior diagnosis of any disease.

To our knowledge, no studies have been done in developing countries that specifically examine characteristics associated with hospital admissions among older adults. The present study, utilizing data obtained from the baseline of a Brazilian prospective study on health of the elderly (The Bambuí Health and Aging Study - BHAS) (Lima-Costa et al., 2000b) aims at identifying characteristics associated with the occurrence of hospital admissions among older adults.

Material and methods

Study area

The municipality of Bambuí has around 20,000 inhabitants, $70 \%$ of whom lived in the urban area (Bambuí town) in 1991 (IBGE, 1992). The 
human development index in the municipality during that year was 0.70 , life expectancy at birth was 70.2 years and $75 \%$ of deaths occurred among people $\geq 50$ years of age (FJP/IPEA, 1996). The leading causes of deaths in the municipality in 1996 were stroke (ICD-10: I60-I69), Chagas disease (ICD-10: B57), ischaemic heart disease (ICD-10: I-20-I25), and pulmonary chronic obstructive disease (ICD-10: J43, J44) (death rates $=110.0,61.4,42.5$ and 18.9 per 100,000, respectively) (DATASUS, 1998; OMS, 1995). The high mortality rate due to Chagas' disease among the resi dents of this community is the consequence of past exposure to infection with Trypanosoma cruzi. Transmission of infection has been interrupted in the municipality for over 20 years, however seropositivity remains high among the el derly due to the cohort effect (Lima-Costa et al., in press).

The town of Bambuí possesses a general hospital with 62 beds and a polyclinic municipal that offers $24 \mathrm{hr}$. Primary Health Care. In 1996 there was one doctor per 1,000 inhabitants of the municipality. In that year, 545 public hospital admissions were registered under the public health system (Sistema Único de Saúde) for residents of Bambuí aged $\geq 60$ years (DATASUS, 1997). Among these, the principal causes were cardiac insufficiency (CID-9: 428) and bacterial pneumonia (CID-9: 482, 485, 486) (admission rates $=28.9$ and 25.2 per 1,000 inhabitants respectively) (OMS, 1985).

Study population

A complete census of the town of Bambuí was carried out by our research team in November and December 1996 to identify the participants of the study. All those aged $\geq 60$ years old on January 1st 1997 were selected to participate in the baseline of the cohort study. More details can be seen in Lima-Costa et al. (2000b).

\section{Study variables}

The dependent variable of this study was the number of hospital admissions during the last 12 months (none, one and two or more). Hospitalization was defined by passing at least one night in hospital as a patient (Coroni-Huntley et al., 1986).

Selection of independent variables for the present study followed the model proposed by Andersen (Aday \& Andersen, 1974; Andersen, 1995; Andersen \& Newman, 1973) to investigate characteristics associated with health service use. According to this model, the individ- ual determinants of the utilization of health services are grouped into indicators of predisposing, enabling and need. The variables of predisposing refer to characteristics whose existence precedes the occurrence of any specific episode of disease (gender, age and beliefs with respect to the efficacy of medical treatments are examples of predisposing). Enabling variables are factors that make the health services available to the individual (income and covering for health plans are examples of enablers). Variables of need represent more immediate causes for the utilization of health services (history of previous diagnosis of any disease and self-perceived health status are examples of indicators of need).

The indicator variables of predisposing in the present study were the following: (1) age in years (60-69, 70-79, $\geq 80$ years), (2) gender (male, female), (3) marital status (married/living together, single, separate/ divorced, widowed), (4) educational level in completed years of schooling (none, 1-3, 4-7, $\geq 8$ ) and (5) living alone (yes or no).

The indicator variables of enabling were: (1) family income $(<2,2-3,4-5, \geq 6)$ and (2) individual income $(<1,1,2-3, \geq 4)$ in minimum Brazilian wages at the time of interview, (3) coverage by private health plan (yes or no), (4) principal problem perceived when medical services needed (none, difficulty of access to local attendance center, other), (5) principal problem perceived with regard to obtaining medication (none, financial, others). The indicator variables of need were the following: (1) report of previous medical diagnosis of selected diseases/conditions (coronary disease angina pectoris and/ or myocardial infarction, arterial hypertension, arthritis, diabetes and Chagas'disease) (yes or no), (2) self-perceived health status during the past 6 months (very good/good, reasonable, bad/very bad), (3) ability to walk at least $1.5 \mathrm{~km}$ without tiring (yes or no), (4) disability to carry out at least one of the following activities of daily life: bathing, dressing, transferring from a bed to a chair, use the bathroom or feed oneself alone (yes or no), (5) unable to carry out routine activities during the last two weeks due to health problems (yes or no), (6) bedridden in some moment in the last two weeks due to health problems (yes or no), (7) number of visits to a doctor in the last 12 months $(\leq 2,3-4, \geq 5)$, (8) number of medications prescribed by a doctor and used in the last 3 months (none, 1-2, 3-4 and $\geq 5$ ). 


\section{Data collection}

The information for the present study was obtained through an interview carried out in the baseline of the cohort study, using the BHAS questionnaire. These interviews lasted approximately 90 minutes and were carried out in the homes of the interviewees. When the interviewee was unable to respond to the interview, due to a cognitive deficit or for some other health reason, an appropriate proxy respondent was used (Magaziner, 1992; Nelson et al., 1990). These proxy did not answer questions that depended on personal judgement, such as self-perceived health status. More details are provided in Lima-Costa et al. (2000b).

\section{Data analysis}

Univariate analysis was based on Pearson's chisquare test and chi-square test for linear trend (Armitage \& Berry, 1987). Multivariate analysis was based on the adjusted odds ratios (OR) and on their confidence intervals at the $95 \%$ level obtained by Woolf's method (Schlesselman, 1982). The OR were adjusted by logistic multinomial regression (Hamilton, 1993; Hosmer \& Lamershow, 1989), taking as reference class the absence of hospital admissions in the last 12 months. Age and sex were considered a priori to be potential confounding variables in this study. All other variables that are in the univariate analysis presented association with the number of hospital admissions below the 0.20 significance level were examined in the multivariate analysis (Greenland, 1989).

Multivariate analysis was carried out initially by each of the three groups of determinants (predisposing, enabling or need) following which the final model was constructed, including all the variables that were associated with the number of hospital admissions at $<0.20$ level in each group of determinants.

\section{Results}

Of the 1,742 elderly selected, 1,606 (92,2\%) participated in the present study. Sixty percent of the participants were female and the median age was 68 years. Of these individuals, 1,244 (77.5\%), 250 (15.6\%) and $112(7.0 \%)$ reported having had no, one and $\geq 2$ hospital admissions in the last 12 months, respectively.

The results of the univariate analysis of the indicators of predisposing for health service utilization, according to the number of hospi- tal admissions are presented in Table 1. All the variables studied (gender, age, marital status, living alone, complete years of schooling) were associated with the number of hospital admissions during the last 12 months.

The totals of the univariate analysis of the indicators of enabling for health service use are presented in Table 2. Among these variables, only coverage by health plan was not significantly associated with the number of hospital admissions at $<0.05$ level $(p=0.058)$. All the others (family and individual income, report of problems of access to local medical attention and financial problems in obtaining medication) were statistically associated with the number of admissions.

The results of the univariate analysis of the indicators for need of utilization of health services are presented in Tables 3 and 4, and are based on the number of hospital admissions. All of these presented a significant association with the number of hospital admissions in the last 12 months ( $p<0.05$ ): number of visits to the doctor during the last 12 months, number of prescribed medications used in the last three months, inability to perform routine activities because of a health problem during the last two weeks, having been bedridden during the last two weeks, inability to walk $1.5 \mathrm{~km}$ without tiring, disability to carry out one or more daily activities, poor self-perceived health status in the last six months, positive medical history of coronary disease, arterial hypertension, arthritis, diabetes and Chagas' disease.

The final results of the multivariate analysis of factors associated with the occurrence of hospitalizations in the last 12 months are presented in Table 5. The following variables were independently associated with reports of one and two or more hospital admissions: greater number of visits to the doctor in the last 12 months ( $3-4$ and $\geq 5$ ), use of greater numbers of prescribed medications in the last three months, having stopped carrying out some activity for a health problem in the past two weeks, having been bedridden in the last two weeks and an inability to walk $1.5 \mathrm{~km}$ without tiring. The male sex, living alone, report of financial problems to obtain medication, selfperceived health as bad/very bad and requiring a proxy respondent to answer the interview were independently associated only with the report of two or more hospitalizations. 
Distribution of indicators of predisposing for utilization of health services, according to the number of hospital admissions during the last 12 months among older adults. Bambuí, Minas Gerais State, Brazil, 1997.

\begin{tabular}{|c|c|c|c|c|}
\hline & \multicolumn{4}{|c|}{ Number of admissions } \\
\hline & $\begin{array}{c}\text { None } \\
(n=1,244) \\
\%\end{array}$ & $\begin{array}{c}\text { One } \\
(n=250) \\
\%\end{array}$ & $\begin{array}{l}\text { Two or more } \\
(\mathrm{n}=112) \\
\%\end{array}$ & $p$ value* \\
\hline \multicolumn{5}{|l|}{ Gender } \\
\hline Female & 57,9 & 69,6 & 62,5 & \\
\hline Male & 42,1 & 30,4 & 37,5 & 0,002 \\
\hline \multicolumn{5}{|l|}{ Age (years) } \\
\hline $60-69$ & 59,4 & 55,6 & 49,1 & \\
\hline $70-79$ & 30,8 & 30,0 & 29,5 & \\
\hline$>80$ & 9,8 & 14,4 & 21,4 & 0,002 \\
\hline \multicolumn{5}{|l|}{ Marital status } \\
\hline Married/live together & 51,0 & 38,8 & 47,3 & \\
\hline Single & 10,5 & 12,0 & 8,9 & \\
\hline Divorced/separated & 4,8 & 6,8 & 4,5 & \\
\hline Widow & 33,7 & 42,4 & 39,3 & 0,031 \\
\hline \multicolumn{5}{|l|}{ Living alone } \\
\hline Yes & 14,5 & 19,2 & 22,3 & \\
\hline No & 85,5 & 80,4 & 77,7 & 0,026 \\
\hline \multicolumn{5}{|l|}{ Years of schooling } \\
\hline None & 30,3 & 38,4 & 44,6 & \\
\hline $1-3$ & 33,4 & 28,4 & 33,9 & \\
\hline $4-7$ & 27,7 & 25,6 & 19,6 & \\
\hline$>8$ & 8,5 & 7,2 & 1,8 & 0,003 \\
\hline
\end{tabular}

* Pearson chi-square test

\section{Discussion}

The characteristics most strongly associated with the occurrence of hospital admissions in the present study were the indicators of need. The magnitude of the associations was greater when two or more hospitalizations were considered. This result is consistent with that observed in two sectional studies (Branch et al., 1981; Hurd \& McGurry, 1997) and a populationbased prospective study (Boult et al., 1993) performed in the United States. It is important to emphasize that the indicators of need were also the ones most strongly associated with use of health services in general (ambulatory, hospital and others) in previous studies carried out in M exico (Borges-Yáñes \& Gómes-Dantés, 1998) and Brazil (Travassos \& Pinheiro, 1999).

Among the indicator variables of need, it is worth calling attention to the self-perceived health status, which in the present study was strongly associated with the occurrence of two or more hospitalizations. This indicator has consistently been found to be associated with the occurrence of hospital admissions among the elderly both in developed countries (Boult et al., 1993; Branch et al., 1981) and developing countries (Fernández-de-la-Hoz \& Leon, 1996). It is also important to emphasize that poor selfperceived health status has been a robust predictor of mortality among old people in different countries and cultures (Helmer et al.; 1999; Korten et al., 1999; Menec et al., 1999; Onawola et al., 1998).

The other indicator variables of need found to be independently associated with the occurrence of hospitalizations in the present study (visits to a doctor, medications prescribed, inability to perform activities due to health problems, bedridden state and an inability to walk $1.5 \mathrm{~km}$ without tiring), are also in agreement with the findings of studies carried out in de- 
Distribution of indicators of enabling for utilization of health services, according to the number of hospital admissions during the last 12 months among older adults. Bambuí, Minas Gerais State, Brazil, 1997.

\begin{tabular}{|c|c|c|c|c|}
\hline & \multicolumn{4}{|c|}{ Number of hospital admissions } \\
\hline & $\begin{array}{c}\text { None } \\
(\mathrm{n}=1,244) \\
\%\end{array}$ & $\begin{array}{c}\text { One } \\
(n=250) \\
\%\end{array}$ & $\begin{array}{c}\text { Two or more } \\
(\mathrm{n}=112) \\
\%\end{array}$ & $p$ value** \\
\hline \multicolumn{5}{|l|}{ Monthly family income* } \\
\hline$<2,00$ & 27,5 & 32,8 & 48,2 & \\
\hline $2,00-3,99$ & 38,3 & 36,0 & 32,1 & \\
\hline $4,00-5,99$ & 14,9 & 15,6 & 10,7 & \\
\hline$\geq 6$ & 18,6 & 13,6 & 8,0 & 0,000 \\
\hline \multicolumn{5}{|c|}{ Monthly personnel income* } \\
\hline$<1,00$ & 11,4 & 10,4 & 10,7 & \\
\hline $1,00-1,99$ & 59,9 & 65,2 & 77,7 & \\
\hline $2,00-3,99$ & 15,4 & 12,4 & 8,0 & \\
\hline$\geq 4,00$ & 13,0 & 12,0 & 3,6 & 0,006 \\
\hline \multicolumn{5}{|l|}{ Private health plan } \\
\hline No & 80,1 & 80,0 & 89,3 & \\
\hline Yes & 19,9 & 20,0 & 10,7 & 0,058 \\
\hline \multicolumn{5}{|c|}{ Major problem to access medical services } \\
\hline None & 36,2 & 28,8 & 20,5 & \\
\hline $\begin{array}{l}\text { Difficulties of access to } \\
\text { medical services local }\end{array}$ & 8,3 & 16,8 & 20,5 & \\
\hline Others & 55,1 & 53,6 & 58,0 & 0,000 \\
\hline \multicolumn{5}{|c|}{ Major problem in obtaining medication } \\
\hline None & 52,7 & 44,0 & 23,2 & \\
\hline Financial problem & 39,9 & 47,6 & 65,2 & \\
\hline Others & 7,2 & 7,6 & 10,7 & 0,000 \\
\hline
\end{tabular}

* In Brazilian minimum wages (US\$ 120.00 , during the study period)

** Pearson chi-square test

veloped countries (Boult et al., 1993; Branch et al., 1981).

The use of a greater number of medications prescribed was independently associated with one and two or more hospitalizations in the last 12 months. Two hypotheses may be raised to explain this finding: first, the number of medications prescribed may reflect a worse state of health; and the second, the risk may be related to the concomitant use of diverse drugs, this being common among the elderly (Borges-Yáñes \& Gómes-Dantés,1998; Mosegui et al, 1999). A study carried out in Sweden demonstrated that $25 \%$ of hospitalizations were related to adverse effects of medications and that the risk of these reactions increased with the number of drugs used (Cadigan et al., 1989). In Brazil, the quality of medication use in elderly people was investigated by Mosegui et al. (1999), who showed that the occurrence of medication interaction and other problems elevated the risk of adverse reactions.

In a cohort study carried out in the United States, it was shown that the medical history report of coronary disease was associated with the occurrence of hospitalizations. Other chronic diseases/ conditions such as arterial hypertension, diabetes and arthritis did not present this association (Boult et al., 1993). Similar results were obtained in the present study.

The existence of an association between disability to perform one or more ADLs and the occurrence of hospital admission was observed in two cross sectional studies carried out in the United States, (Branch et al., 1981; Hurd \& McGurry, 1997), but this association was not found in a cohort study performed in the same country (Boult et al., 1993). In the present study, 
Distribution of select indicators for the need of health services utilization, according to the number of hospital admissions during the last 12 months among older adults. Bambuí, Minas Gerais State, Brazil, 1997.

\begin{tabular}{|c|c|c|c|c|}
\hline & \multicolumn{4}{|c|}{ Number of hospital admissions } \\
\hline & $\begin{array}{c}\text { None } \\
(\mathrm{n}=1,244) \\
\%\end{array}$ & $\begin{array}{c}\text { One } \\
(n=250) \\
\%\end{array}$ & $\begin{array}{c}\text { Two or more } \\
(\mathrm{n}=112) \\
\%\end{array}$ & $p$ value* \\
\hline \multicolumn{5}{|c|}{$\begin{array}{l}\text { Number of visits to a doctor } \\
\text { during the last } 12 \text { months }\end{array}$} \\
\hline$\leq 2$ & 62,8 & 38,4 & 11,6 & \\
\hline $3-4$ & 9,8 & 27,2 & 29,5 & \\
\hline$\geq 5$ & 17,4 & 34,4 & 58,9 & 0,000 \\
\hline \multicolumn{5}{|c|}{$\begin{array}{l}\text { Use of prescribed medications } \\
\text { during the last } 3 \text { months }\end{array}$} \\
\hline None & 24,1 & 8,4 & 3,6 & \\
\hline $1-2$ & 30,8 & 25,6 & 13,4 & \\
\hline $3-4$ & 27,2 & 30,4 & 36,6 & \\
\hline$\geq 5$ & 17,9 & 35,6 & 46,4 & 0,000 \\
\hline \multicolumn{5}{|c|}{$\begin{array}{l}\text { Unable to perform routine activities because } \\
\text { of a health problem during the last } 2 \text { weeks }\end{array}$} \\
\hline Yes & 12,0 & 30,0 & 43,8 & \\
\hline No & 88,0 & 69,6 & 56,2 & 0,000 \\
\hline \multicolumn{5}{|c|}{$\begin{array}{l}\text { Having been bedridden } \\
\text { during the last two weeks }\end{array}$} \\
\hline Yes & 6,4 & 19,2 & 32,1 & \\
\hline No & 93,5 & 80,4 & 67,9 & 0,000 \\
\hline \multicolumn{5}{|c|}{ Capacity to walk $1.5 \mathrm{~km}$ without tiring } \\
\hline Yes & 55,3 & 34,0 & 17,9 & \\
\hline No & 44,6 & 66,0 & 82,1 & 0,000 \\
\hline \multicolumn{5}{|c|}{ Disability in one or more ADLs** } \\
\hline Yes & 7,1 & 16,4 & 20,5 & \\
\hline No & 92,8 & 82,8 & 79,5 & 0,000 \\
\hline
\end{tabular}

* Pearson chi-square

** ADLs = activities of daily living (bathing, dressing, transferring, using the toilet or eating)

the association between disability to carry out at least one among five ADLs and the occurrence of hospital admissions encountered in the univariate analysis was not maintained after adjustments by confounding variables.

With respect to the indicator variables of predisposing for hospitalizations, none was associated with the occurrence of a single hospital admission. The male sex and living alone presented independent associations with the occurrence of two or more hospital stays. The greater occurrence of hospitalization among men, also observed in other studies (Boults et al., 1993) could signify that men seek medical assistance later than women and that the entry point to the health system for elderly male resi- dents of Bambuí could be the hospital. The association between living alone and the occurrence of hospital stays, observed in the present study, was not found in previous studies carried out in developed countries. Our results suggest that in the community studied, hospitalization may be a substitute for lack of adequate household care. Among the enabling indicators, we observed that only the report of financial constraints to obtain medication was associated with the occurrence of two or more hospital admissions. In spite of the lack of similar findings in other studies, our results are consistent with those which would be expected under a health system that is still unprepared to attend to the elderly population, and in 
Distribution of select indicators for the need of health services utilization, according to the number of hospital admissions during the last 12 months among older adults. Bambuí, Minas Gerais State, Brazil, 1997.

\begin{tabular}{|c|c|c|c|c|}
\hline & \multicolumn{4}{|c|}{ Number of hospital admissions } \\
\hline & $\begin{array}{c}\text { None } \\
(\mathrm{n}=1,244) \\
\%\end{array}$ & $\begin{array}{c}\text { One } \\
(n=250) \\
\%\end{array}$ & $\begin{array}{c}\text { Two or more } \\
(\mathrm{n}=112) \\
\%\end{array}$ & p value* \\
\hline \multicolumn{5}{|c|}{ Self-perceived health status during the last 6 months } \\
\hline Very good/good & 26,3 & 18,0 & 2,7 & \\
\hline Reasonable & 49,1 & 43,6 & 23,2 & \\
\hline Bad/very bad & 20,3 & 29,6 & 61,6 & \\
\hline Not informed** & 4,3 & 8,8 & 12,5 & 0,000 \\
\hline \multicolumn{5}{|c|}{ Report of medical history of coronary disease } \\
\hline Yes & 9,2 & 12,4 & 24,1 & \\
\hline No & 89,8 & 17,9 & 75,0 & 0,000 \\
\hline \multicolumn{5}{|c|}{ Report of medical history of hypertension } \\
\hline Yes & 55,7 & 59,2 & 67,9 & \\
\hline No & 44,3 & 40,8 & 32,1 & 0,007 \\
\hline \multicolumn{5}{|c|}{ Report of medical history of arthritis } \\
\hline Yes & 24,0 & 28,8 & 34,8 & \\
\hline No & 76,0 & 71,2 & 65,2 & 0,035 \\
\hline \multicolumn{5}{|c|}{ Report of medical history of diabetes } \\
\hline Yes & 10,6 & 12,4 & 18,8 & \\
\hline No & 89,4 & 87,6 & 81,2 & 0,031 \\
\hline \multicolumn{5}{|c|}{ Report of medical history of Chagas's disease } \\
\hline Yes & 22,3 & 33,2 & 36,6 & \\
\hline No & 77,7 & 66,8 & 63,4 & 0,000 \\
\hline
\end{tabular}

* Pearson chi-square

** proxy respondent

which incipient pharmaceutical assistance exists with very high medication prices (Consendey et al., 2000).

There is consistent evidence among older adults that holding a private health plan is associated with increased health service use in general (Cohen et al., 1997; Hurd \& McGarry, 1997; Lima-Costa et al., in press; Travassos et al., 2000). The separate effect of private coverage on hospital admissions was investigated in only one study. In this study, carried out in the United States, it was demonstrated that among people aged $\geq 70$ years, private coverage was positively associated with hospital stays. In Bambuí, we observed a strong and positive association between having private health plan and the number of visits to a doctor or number of prescribed medications used. This association was not substantially affected by adjustments for health status and other confounding variables. Hospitalization, on the other hand, was not found to be associated with private coverage (Lima-Costa et al., in press). The differences between these and the Bambuí's results could be explained, at least in part, by the (1) small proportion of coverage by supplementary health plans in the study population $(20 \%)$ compared to that seen in the American one $(70 \%)$ and (2) by the existence in Brazil of a public health system (Sistema Ú nico de Saúde) which guarantees free hospital care for the whole population. It is important to note that the proportion of those covered by a private health plan in the study community is similar to that observed in Brazil as a role (IBGE, 2000).

Our results show differences between the determinants for the occurrence of a single hospital stay and those for multiple admissions. In general, the study variables are most frequently, and most strongly, associated with 
Final results of the multivariate analysis of factors associated with the occurrence of hospital

admissions in the last 12 months among older adults. Bambuí, Minas Gerais State, Brazil, 1997.

\begin{tabular}{|c|c|c|}
\hline & $\begin{array}{l}\text { One vs None } \\
\text { Hospital admissions } \\
\text { OR (CI 95\%) }\end{array}$ & $\begin{array}{l}\text { Two or more vs None } \\
\text { hospital admissions } \\
\text { OR (Cl } 95 \%)\end{array}$ \\
\hline \multicolumn{3}{|c|}{ Indicators of predisposing } \\
\hline \multicolumn{3}{|c|}{ Age in years (Ref: 60-69) } \\
\hline $70-79$ & $0,89(0,64-1,24)$ & $1,05(0,62-1,78)$ \\
\hline$>80$ & $1,12(0,71-1,76)$ & $1,97(1,05-3,68)$ \\
\hline \multicolumn{3}{|l|}{ Gender (Ref: Female) } \\
\hline Male & $0,86(0,62-1,20)$ & $1,82(1,11-2,98)$ \\
\hline \multicolumn{3}{|l|}{ Living alone (Ref: No) } \\
\hline Yes & $1,44(0,98-2,12)$ & $2,69(1,53-4,74)$ \\
\hline \multicolumn{3}{|l|}{ Indicators of enabling } \\
\hline \multicolumn{3}{|c|}{ Major problem in obtaining medications (Ref: None) } \\
\hline Financial problems & $1,16(0,85-1,58)$ & $2,47(1,46-4,74)$ \\
\hline Others & $0,90(0,51-1,61)$ & $2,04(0,92-4,56)$ \\
\hline \multicolumn{3}{|l|}{ Indicators of need } \\
\hline \multicolumn{3}{|c|}{$\begin{array}{l}\text { Self-perceived health during the last } 6 \text { months } \\
\text { (Ref: Very good/good) }\end{array}$} \\
\hline Reasonable & $0,73(0,48-1,11)$ & $1,71(0,49-5,95)$ \\
\hline Bad/very bad & $0,69(0,42-1,12)$ & $4,74(1,38-16,29)$ \\
\hline Not informed* & $1,42(0,72-2,79)$ & $6,04(1,49-24,48)$ \\
\hline \multicolumn{3}{|c|}{$\begin{array}{l}\text { Number of visits to a doctor during the last } \\
12 \text { months (Ref: } \leq 2 \text { ) }\end{array}$} \\
\hline $3-4$ & $1,70(1,17-2,48)$ & $4,22(2,07-8,58)$ \\
\hline$\geq 5$ & $2,03(1,38-2,99)$ & $6,63(3,33-13,19)$ \\
\hline \multicolumn{3}{|c|}{$\begin{array}{l}\text { Use of prescribed medications during last } \\
3 \text { months (Ref: None) }\end{array}$} \\
\hline $1-2$ & $1,75(1,02-3,00)$ & $1,32(0,38-4,58)$ \\
\hline $3-4$ & $1,85(1,05-3,23)$ & $2,60(0,80-8,43)$ \\
\hline$\geq 5$ & $2,73(1,53-4,88)$ & $3,31(1,01-10,82)$ \\
\hline \multicolumn{3}{|c|}{ Report of medical history of coronary disease (Ref: $\mathrm{No}$ ) } \\
\hline Yes & $0,99(0,63-1,56)$ & $2,04(1,16-3,59)$ \\
\hline \multicolumn{3}{|c|}{$\begin{array}{l}\text { Unable to perform routine activities because of } \\
\text { a health problem in the past } 2 \text { weeks (Ref: } \mathrm{No} \text { ) }\end{array}$} \\
\hline Yes & $1,75(1,17-2,61)$ & $1,88(1,12-3,16)$ \\
\hline \multicolumn{3}{|c|}{ Having been bedridden during last 2 weeks (Ref: No) } \\
\hline Yes & $1,73(1,07-2,81)$ & $1,98(1,10-3,54)$ \\
\hline \multicolumn{3}{|c|}{ Capacity to walk $1.5 \mathrm{~km}$ without tiring (Ref: Yes) } \\
\hline No & $1,52(1,09-2,13)$ & $1,91(1,08-3,38)$ \\
\hline
\end{tabular}

$\mathrm{OR}=$ odds ratio $; \mathrm{Cl}=$ confidence interval - adjusted for all variables listed in the table using multinomial logistic regression (1,579 individuals participated in final analysis) *proxy respondent

Ref $=$ reference 
the occurrence of multiple hospitalizations. This observation is important, since programs of prevention should prioritize the neediest members of the elderly population and consequently, those with the highest probability of multiple hospital stays (Freeborn et al., 1990; Zook \& Moore, 1980).

With regard to the methodology of this study, all efforts were made to avoid bias, such as stimulus to participate, double blind collection of data, standardization of procedures and instruments, as well as exhaustive training of field teams. The response rate in this study was high and the participants were similar to the general population of older adults of Bambuí with respect to all the characteristics investigated: gender, age, marital status, number of residents per domicile, monthly family income and schooling, thus guaranteeing the internal validity of the study (Lima-Costa et al., 2000b). On the other hand, because the information on the occurrence of hospitalizations refers to the previous 12 months, the possibility of recall bias exists. It is unlikely that this has influenced our results; the rate of hospital admissions in the study population (22\%) was very close to that estimated for all residents of Bambuí aged 60 or over, registered under the public health system (26\%) (DATASUS, 1997). Because this is a cross-sectional study, it is impossible to separate cause and effect. Thus, the self-perceived health status as poor could be a consequence of previous hospital stays. However, it is possible that this was not true of the present study, since the importance of self-perceived health status in predicting hospitalizations and other events related to health problems has been confirmed in population-based cohort studies (Boult et al., 1993; Korten et al., 1999). Survival bias is always possible in cross-sectional studies of the older adult population, that is, the most infirm elderly people and consequently, those with the highest number of hospital stays may die earliest. The presence of this bias could diminish the force of the associations among variables, reinforcing those found in this study.

\section{Conclusions}

The results obtained in this study show indicators for the identification of older adults under higher risk of hospitalization. The strongest association with multiple hospital admissions were encountered for (1) living alone, (2) existence of financial constraints to obtaining medication and (3) for diverse indicators of need (self-perceived health status as poor, greater number of visits to the doctor, greater number of prescribed medications used and a history of coronary disease). These results point to measures that could be implemented by the health services for preventive measures, such as: (a) identification of elderly people who live alone in the community, and establishment of routine visits by health service personnel; (b) valorization of repeated requests for medical attention as an indicator of the need for health care and the establishment of adequate attention; (c) implementation of pharmaceutical assistance; (d) incorporation of collection of certain basic items of information (such as self-perceived health status) which could be used to identify individuals with greatest needs into the routine of the health services. The search for indicators and criteria that benefit the orientation and provision of health services for the older adult population should concern researchers and health system workers. Our results, together with those of similar studies carried out in developed countries, indicate that certain simple, easily obtained items of information could be useful in identifying the groups at greatest risk and assist in the elaboration of intervention strategies.

\section{Acknowledgements}

This study was sponsored by the Financiadora de Estudos eProjetos (FINEP). H. L. G., E. U. and M. F. F. L.C. are fellows of the Consel ho Nacional de Desenvolvimento Científico e Tecnológico (CNPq). This study would not have been possible without the collaboration of the population of Bambuí. 
References

ADAY, L. A. \& ANDERSEN, R., 1974. A framework for study of access to medical care. Health Services Research, 9:208-220.

ANDERSEN, R., 1995. Revisiting the behavioral model and access to medical care: Does it matter? Journal of Health and Social Behavior, 36:1-10.

ANDERSEN, R. \& NEWM AN, J. F., 1973. Societal and individual determinants of medical care utilization in the United States. Milbank Memorial Fund Quarterly, 51:95-124.

ARMITAGE, P. \& BERRY, G., 1987. Statistical Methods in Medical Research. Oxford: Blackwell Scientific Publications.

BORGES-YAÑES, A. S. \& GOMES-DANTES, H., 1998. Uso de los servicios de salud por la población de 60 años y más en México. Salud Pública de México, 40:13-23.

BOULT, C.; BOULT, L.; MURPHY, C.; EBBITT, B.; LUPTAK, M. \& KANE, R. L., 1994. A controlled trial of outpatient geriatric evaluation and management. Journal of the American Geriatrics Society, 42:465470.

BOULT, C.; DOWD, B.; MCCAFFEY, B. A.; BOULT, L.; HERNANDEZ, R. \& KRULEWITCH, H., 1993. Screening elders for risk of hospital admission. Journal of the American Geriatrics Society, 41:811817.

BRANCH, L.; JETTE, A.; EVASHWICK, C.; POLANSKY, M.; ROWE, G. \& DIEHR, P., 1981. Toward understanding elder's health service utilization. Journal of Community Health, 7:80-92.

CADIGAN, D.; M AGANIZER, J. \& FEDDER, D., 1989. Polymedicine use among community resident older women: How much of a problem? American Journal of Public Health, 79:1537-1540.

COHEN, R. A.; BLOOM, B.; SIMPSOM, G. \& PEARSONS, E., 1997. Access to health care. Part 3: Older adults. Vital and Health Statistics. Series 10. Data from the National Health Survey, 198:1-32.

COLEMAN, E. A.; WAGNER, E. H.; GROTHAUS, L. C.; HECHT, J.; SAVARINO, J. \& BUCHNER, D. M., 1998. Predicting hospitalizations and functional decline in older health plan enrollees: Are administrative data as accurate as self-report? Journal of the American Geriatrics Society, 46:419-425.

CORONI-HUNTLEY, J. C.; BROCK, D. B.; OSTFELD, A. M.; TAYLOR, J. O. \& WALLACE, R. B., 1986. Established Populations for Epidemiological Studies of the El derly. NIH Publications 86-2443. Washington, DC: National Institute on Ageing.

COSENDEY, M. A. E.; BERMUDEZ, J.; REIS, A. L. A.; SILVA, H. F.; OLIVEIRA, M. A. \& LUIZA, V. L., 2000. Assistência farmacêutica na atenção básica de saúde: A experiência de três estados brasileiros. Cadernos de Saúde Pública, 16:171-182.

DATASUS (Departamento de Informática do SUS), 1997. Movimento de Autorização de Internação Hospitalar; 1996. CD-ROM, Brasília: Ministério da Saúde.

DATASUS (Departamento de Informática do SUS), 1998. Si stema de Informações sobre Mortalidade; 1979-1996. CD-ROM, Brasilía: Ministério da Saúde.

EVANS, R. L.; HENDRICKS, R. D.; LAWRENCE, K. V. \& BISHOP, D. S., 1988. Identifying factors associat- ed with health care use: A hospital-based risk screening index. Social Science and Medicine, 27: 947-954.

FERNANDEZ-DE-LA-HOZ, K. \& LEON, D. A., 1996. Self-perceived health status and iniqualities in use of health services in Spain. International Journal of Epidemiology, 25:593-603.

FREEBORN, D. K.; POPE, C. R.; MULLOOLY, J. P. \& MCFARLAND, B. H., 1990. Consistently high users of medical care among elderly. Medical Care, 28: 567-585.

FJP (Fundação João Pinheiro)/IPEA (Instituto de Pesquisas Econômicas Aplicadas), 1996. Condições de Vida nos Municípios de Minas Gerais, 1970, 1980, 1991. Belo Horizonte: Governo do Estado de Minas Gerais.

GREENLAND, S., 1989. Modeling and variation selection in epidemiologic analysis. American Journal of Public Health, 79:340-349.

HAMILTON, L. C., 1993. Interpreting multinomial Iogistic regression. Stata Technical Bulletin, 13:24-28.

HELMER, C.; BARBERGER-GATEON, P.; LETENNEUR, L. \& DARTIGUES, J. F., 1999. Subjective health and mortality in French elderly women and men, 1999. Journals of Gerontology. Series B, Psychological Sciences and Social Sciences, 54: S84-92.

HOSMER, D. W. \& LAMENSHOW, S., 1989. Applied Logistic Regression. New York: John Wiley \& Sons.

HURD, M. D. \& MCGARRY, K., 1997, Medical insurance and the use of health care services by the elderly. Journal of Health Economics, 16:129-154.

IBGE (Fundação Instituto Brasileiro de Geografia e Estatística), 1989. Censo Demográfico de 1980. Rio de Janeiro: IBGE.

IBGE (Fundação Instituto Brasileiro de Geografia e Estatística), 1992. Censo Demográfico de 1991. Rio de Janeiro: IBGE.

IBGE (Fundação Instituto Brasileiro de Geografia e Estatística), 1997. Contagem da População, 1996. Rio de Janeiro: IBGE.

IBGE (Fundação Instituto Brasileiro de Geografia e Estatística), 2000. PNAD - Acesso e Utilização de Serviços de Saúde. Rio de Janeiro: IBGE.

KALACHE, A.; VERAS, R. P. \& RAM OS, L. R., 1987. O envelhecimento da população mundial. Um desafio novo. Revista de Saúde Pública, 21:200-210.

KATZ, S.; FORD, A. B.; MOSKOWITZ, R. W.; JACKSON, B. A. \& JAFFE, M. W., 1963. Studies of illness in the aged. The index of ADL: A standardized measure of biological and psychological function. JAMA, 185:914-919.

KORTEN, A. E.; JORM, A. F.; JIAO, Z.; LETENNEUR, I.; JACOMB, P. A.; HENDERSON, A. S.; CHRISTENSEN, H. \& RODGERS, B., 1999. Health, cognitive, and psychosocial factors as predictors of mortality in an elderly community sample. Journal of Epidemiology and Community Health, 53:83-88.

LIMA-COSTA, M. F. F.; BARRETO, S. M.; GUERRA, H. L.; FIRMO, J. O. A.; UCHOA, E. \& VIDIGAL, P. G., in press. Ageing with Trypanosoma cruzi infection in a community where the transmission has been interrupted: The Bambuí Health and Ageing Study (BHAS). International Journal of Epidemiology. 
LIMA-COSTA, M. F. F.; GUERRA, H. L.; BARRETO, S. M. \& MAIA, R., 2000a. Diagnóstico da situação de saúde da população idosa brasileira: Um estudo da mortalidade e das hospitalisations hospitaIares públicas. Informe Epidemiológico do SUS, 9:23-41.

LIMA-COSTA, M. F. F.; UCHOA, E.; GUERRA, H. L.; FIRMO, J. O. A.; VIDIGAL, P. G. \& BARRETO, S. M., 2000b. The Bambuí Health and Ageing Study (BHAS): Methodological approach and preliminary results of a population-based cohort study of the elderly in Brazil. Revista de Saúde Pública, 34:126-135.

LIMA-COSTA, M. F. F.; UCHOA, E.; GUERRA, H. L.; FIRMO, J. O. A.; VIDIGAL, P. G. \& BARRETO, S. M., in press. The Bambuí Health and Ageing Study (BHAS): Private health plan and medical care utilization by older adults. Cadernos de Saúde Pública.

MAGAZINER, J., 1992. The use of proxy respondents in health studies of the aged. In: The Epidemiologic Study of the Elderly (R. B. Wallace \& R. F. Woolson, ed.), pp. 120-129, New York: Oxford University Press.

MCCALL, N. \& WAI, H. S., 1983. An analysis of use of Medicare services by the continuously enrolled aged. Medical Care, 21:567-585.

MENEC, V. H.; CHIPPERFIELD, J. G. \& PERRY, R. P., 1999. Self-perceptions of health: A prospective analysis of mortality, control, and health. Journals of Gerontology. Series B, Psychological Sciences and Social Sciences, 54:85-93.

MOSEGUI, G. B. G.; ROSENFELD, S.; VERAS, R. P. \& VIANNA, C. M. M., 1999. Avaliação da qualidade do uso de medications em idosos. Revista deSaúdePública, 33:437-444.

NELSON, L. M.; LONGTRETH, W. T.; KOEPSELL, T. D. \&VAN BELLE, G., 1990. Proxy respondents in epidemiologic research. Epidemi ol ogic Reviews, 12: 71-86.

OMS (Organização Mundial da Saúde), 1985. Classificação Estatística Internacional de Doenças: Manual de Lesões e Causas de Óbito. 9a Revisão, v. 1. São Paulo: Centro Colaborador da OMS para a Classificação de Doenças em Português.

OMS (Organização Mundial da Saúde), 1995. Classificação Estatística Internacional de Doenças e Problemas Relacionados à Saúde. 10a Revisão, v. 1. São Paulo: Centro Colaborador da OMS para a Classificação de Doenças em Português.
ONAWOLA, R. S. \& LA VEIST, T. A., 1998. Subjective health status as a determinant of mortality among African-American elders. Journal of the National Medical Association, 90:754-758.

PACALA, J. T.; BOULT, C.; REED, R. L. \& ALIBERTI, R. N., 1997. Predictive validity of $P_{r a}$ instrument among older recipients of managed care. Journal of the American Geriatric Society, 45:614-617.

PINHEIRO, R. S. \& TRAVASSOS, C., 1999. Estudo da desigualdade na utilização de serviços de saúde por idosos em três regiões da cidade do Rio de Janeiro. Cadernos deSaúdePública, 15:487-496.

RAMOS, L. R.; VERAS R. P. \& KALACHE, A., 1987. EnveIhecimento populacional: Uma realidade brasileira. Revista deSaúde Pública, 21:211-223.

ROOS, N. P. \& SHAPIRO, E., 1981. The Manitoba longitudinal study on aging: Preliminary findings on health care utilization by the elderly. Medical Care, 19:644-657.

ROOS, N. P.; SHAPIRO, E. \& TATE, R., 1989. Does a small minority of elderly account for a majority of health care expenditures? A sixteen-year perspective. Milbank Memorial Fund Quartely, 67: 347-369.

SATISH, S.; WINOGRAD, C. H.; CHAVES, C. \& BLOCH, D. A., 1996. Geriatric targeting criteria as predictors of survival and health care utilization. Journal of the American Geriatric Society, 44:914-921.

SCHLESSELMAN, J. J., 1982. Case-Control Studies. De sign, Conduct Analysis. New York: Oxford University Press.

TAKET, S. R., 1992. Resource allocation problems and health services for the elderly. World Health Statistics Quarterly, 45:89-94.

TRAVASSOS, C.; VIACAVA, F.; FERNANDES, C. \& ALMEIDA, C., 2000. Desigualdades geográficas e sociais na utilização de serviços de saúde no Brasil. Ciência \& SaúdeColetiva, 1:133-148.

VERAS, R. P.; RAMOS, L. R. \& KALACHE, A., 1987. Crescimento da população idosa no Brasil. Transformações e conseqüências na sociedade. Revista deSaúdePública, 21:225-233.

WHO (World Health Organization), 1998. Population Ageing: A Public Health Challenge. Geneva: WHO Press Office.

WOLINSKY, F. D.; JOHNSON, R. J. \& FITZGERALD, J. F., 1992. Falling health status and the use of health services by older adults. Medical Care, 30:587-597.

ZOOK, C. J. \& MOORE, F. D., 1980. High-cost users of medical care. New England Journal of Medicine, 302:996-1002. 